\title{
Böcek Virüslerinin Biyoteknolojik Önemi
}

\author{
İsmail DEMIR ${ }^{1} \quad$ Remziye NALÇACIOĞLU ${ }^{1} \quad$ Zihni DEMIRBAĞ ${ }^{1}$
}

Geliş Tarihi: 11.07.2007 Kabul Tarihi: 15.04.2008

\begin{abstract}
Öz: Böcek virüsleri, böcekleri enfekte ederek, onların hastalanmaları veya ölmelerine neden olan biyolojik etmenlerdir. Son yıllarda, bu virüsler modern biyoteknoloji uygulamalarında önemli ölçüde ilgi uyandırmaktadır. Yüksek konukçu seçiciliklerine sahip böcek virüsleri, çeşitli tarım ve orman zararılırına karşı kimyasal pestisitlerin alternatifi olarak kullanılmaktadır. Bu virüslerle yapılan çalışmalar yüksek organizasyonlu canlılar için model olarak kullanılmaktadır. Endüstriyel, zirai, tıbbı ve ekonomik öneme sahip ilgi duyulan birçok gen, bu virüslerden geliştirilmiş ekspresyon vektörlerinde bol miktarda üretilmektedir. Ayrıca, son yıllarda bu virüsler gen terapi vektörü olarak da kullanılmaktadır. Bu derleme makalede, başta genel böcek virüsleri olmak üzere bakülovirüslerin çeşitli biyoteknolojik çalışmalarda kullanılma potansiyelleri üzerinde durulacaktır.
\end{abstract}

Anahtar Kelimeler: Böcek virüsleri, biyoteknoloji, bakülovirüsler

\section{The Significance of Insect Viruses in Biotechnology}

Abstract: Insect viruses are biological control agents that cause their illness or dead by infecting the insects. Recently, these viruses have great interest at modern biotechnological applications. Insect viruses that have high host specificity, have been used against various agricultural and forest pest as an alternative to chemical pesticides. Studies done with these viruses have been used as model for high organizational organisms. Many genes that has industrial, agricultural, medical and economical importance have been produced at great amounts at expression systems developed from these viruses. Also, recently these viruses are being used as gene therapy vector. At this review paper, we will pay attention on subjects especially at insect viruses, and potential of the usage of baculoviruses at various biotechnological studies.

Key Words: Insect viruses, biotechnology, baculoviruses

\section{Giriş}

Böcekler, dünyada en çok çeşitliliğe sahip olan hayvanlar olup, canlılar aleminin belki de en kalabalık sınıfıdır. Dünyada tanımı yapılan hayvan türlerinin 4/5'ini böcekler oluşturmaktadır (URL1). Böcekler ve insanlar yeryüzünde birlikte yaşamaktadır ve bu nedenle aralarında karmaşık ilişkiler vardır. Doğada yaşayan böceklerin \%99'dan fazlasının insanlar için faydalı olduğu bilinmektedir. Bilinen yaklaşık 1 milyon 300 bin böcek türünün, sadece \%1'den daha az doğaya ve insanlığa zarar vermektedir (URL2). Sayısal olarak az olmalarına rağmen bu zararlıların etkileri oldukça büyük olmaktadır.

Çeşitli mikrobiyal etmenler böceklerde doğal enfeksiyonlar meydana getirmektedir (Tanada ve Kaya 1993, Boucias ve Pendland 1998, Charles ve ark. 2000). Böcek virüsleri onların hastalanmalarına ve ölümlerine sebep olan doğal etmenlerin başında yer almaktadır (Hunter-Fujita ve ark. 1998, Miller ve Ball 1998). Doğaya ve insanlara yaptıkları etkilere göre böcek virüslerini iki açıdan ele almak gerekir. Bunların birincisi, ipek böceği ve bal arıları gibi insanlara ve çevreye faydalı olan böceklerin hastalanıp ölmelerine sebep olmalarıdır. İkincisi ise fındık kurdu, ladin kabuk böceği, amerikan beyaz kelebeği, sivrisinek gibi çeşitli tarım ve orman ürünlerini veya insan sağlığını etkileyen zararlı böcekleri enfekte etmeleridir.

Bugüne kadar çok sayıda böcek virüsü izole edilmiş ve tanımlanmıştır. Sadece 800'dan fazla bakülovirüs Arthropod'lardan izole edilmiştir (Murphy ve ark. 1995). Bu virüsler temel biyolojik olayların anlaşılmasına yardımcı olan araştırmaların yapıldığı önemli deney materyalleridir (Bilimoria 1991, Demir 2004). Ayrıca, böcek virüsleri tarım ve ormancılıkta zararlı böceklerle mücadelede kullanılan önemli biyolojik mücadele etmenleridir (Flexner ve Belnavis 2000, Harrison ve Bonning 2000, Sezen ve Demirbağ 2005). Böcek virüsleri uzun zamandan beri tıbbi, ekonomik ve endüstriyel bakımdan önemli çeşitli proteinlerin üretildiği gen ekspresyon vektörleri olarak 
biyoteknolojide kullanılmaktadır (King ve Possee 1992 Demirbağ ve ark. 1998, Demir ve ark. 2000, Beljelarskaya 2002). Ayrıca son yıllarda bu virüslerin gen terapi vektörleri olarak memeli hücre sistemlerine gen transferinde kullanılmalarına yönelik çalışmalar da yoğunlaşmıştır (Ghosh ve ark. 2002, Hu 2006). $\mathrm{Bu}$ derleme eserde böcek virüslerinin temel özellikleri hakkında genel bilgiler verildikten sonra böcek virüslerinin biyoteknolojik önemleri üzerinde durulacaktır.

Böcek virüslerinin genel özellikleri: Böcek virüsleri şimdiye kadar böceklerden izole edilmiş en küçük formlardır. Bir nükleik asit ve bunu çevreleyen protein bir örtüye (kapsid) sahiptirler. Bazılarında da nükleik asit ve kapsidi çevreleyen lipid bir zarf mevcuttur. Bazı virüsler etraflarını çevreleyen protein örtünün yanı sıra başka bir protein yapı içine de gömülmüş olabilirler. Bu yapı inklüzyon cisimciğ olarak adlandırılır. İnklüzyon yapılar içerisine gömülü halde olan virüsler gömülü virüsler (OV) olarak adlandırııılar. İnklüzyon yapılar şimdiye kadar sadece Baculoviridae, Reoviridae ve Poxviridae gibi virüs familyalarında tespit edilmiştir (Hunter-Fujita ve ark. 1998). Böceklerden izole edilen virüslerin, genom özellikleri, kaydedildikleri konukçu takımları ve konukçularının biyolojik dönemleri Çizelge 1'de özetlenmiştir.

Başta bakülovirüsler, reovirüsler, entomopoksvirüsler ve iridovirüsler olmak üzere hemen hemen bütün böcek virüsleri biyoteknolojik amaçla kullanılmaktadır (Nalçacıoğlu 2003, Demir 2004, Sezen 2004). Ancak, şu ana kadar en çok çalışılan ve biyoteknolojik amaçla en yoğun kullanılan böcek virüsleri bakülovirüslerdir (Possee 1997, Inceoğlu ve ark. 2001, Kost ve ark. 2005, Knipe ve ark. 2007, URL3). Bu nedenle, konuların daha iyi anlaşılması için burada özellikle bakülovirüslerin özelliklerinden ve biyoteknolojik kullanımlarından bahsedilecektir.

Bakülovirüslerin biyolojisi: Bakülovirüsler $25 \times 250 \mathrm{~nm}$ büyüklükte ve $80-180 \mathrm{kbp}$ kapalı yuvarlak ve çift zincir, süpersarmal DNA ihtiva ederler (Hayakawa ve ark. 2000, Herniou ve ark. 2001, Theilmann ve ark. 2005). Virüs DNA'sı, hücre zarı yapısına benzer ve karmaşık yapıda olan bir zarf ile çevrili nükleokapsid içerisine paketlenmiştir.

İntrasellüler virüsler, polihedra veya granula olarak isimlendirilen protein yapısında inklüzyon yapılar içerisine gömülürler. Baculoviridae familyası inklüzyon yapıların şekline göre nükleopolihedrovirüs ve granulozis virüs olmak üzere iki alt cinse ayrılır (Slack ve Arif 2007). Bu gruplandırma morfolojik, serolojik ve genetik bilgilere dayanılarak yapılmaktadır.
Çizelge 1. Böceklerden izole edilen virüslerin familyaları, genom özellikleri ve tespit edildikleri konukçu takımlar*

\begin{tabular}{|c|c|c|c|}
\hline Virüs Familyaları & Genom & $\begin{array}{l}\text { Kaydedildiği } \\
\text { konukçu } \\
\text { takımlar }\end{array}$ & $\begin{array}{l}\text { Genel } \\
\text { konukçu } \\
\text { dönemleri }\end{array}$ \\
\hline $\begin{array}{l}\text { Baculoviridae: NPV v } \\
\text { GV }\end{array}$ & dsDNA & $\begin{array}{l}\text { Coleoptera, } \\
\text { Diptera, } \\
\text { Hymenoptera, } \\
\text { Lepidoptera, } \\
\text { Neuroptera, } \\
\text { Siphonaptera, } \\
\text { Thysanura, } \\
\text { Trchoptera }\end{array}$ & $\begin{array}{l}\text { Larva, } \\
\text { bazen } \\
\text { pupa veya } \\
\text { ergin }\end{array}$ \\
\hline Reoviridae: CPV & dsRNA & $\begin{array}{l}\text { Diptera, } \\
\text { Hymenoptera, } \\
\text { Lepidoptera }\end{array}$ & $\begin{array}{l}\text { Larva, } \\
\text { pupa, ergin }\end{array}$ \\
\hline Entomopoxviridae: EF & IdsDNA & $\begin{array}{l}\text { Coleoptera, } \\
\text { Diptera, } \\
\text { Hymenoptera, } \\
\text { Lepidoptera, } \\
\text { Orthoptera }\end{array}$ & Larva \\
\hline Iridoviridae: IV & dsDNA & $\begin{array}{l}\text { Hemen hemen } \\
\text { tüm böcekler } \\
\text { ve diğer } \\
\text { omurgasız } \\
\text { familyaları }\end{array}$ & Larva \\
\hline Ascoviridae & dsDNA & $\begin{array}{l}\text { Lepidoptera } \\
\text { (sadece } \\
\text { Noctuidae } \\
\text { familyası) }\end{array}$ & Larva \\
\hline Polydnaviridae & dsDNA & $\begin{array}{l}\text { Parazitik } \\
\text { Hymenoptera }\end{array}$ & Ergin \\
\hline Parvoviridae: DNV & ssDNA & $\begin{array}{l}\text { Diptera, } \\
\text { Blattoidae, } \\
\text { Lepidoptera, } \\
\text { Odonata, } \\
\text { Orthoptera }\end{array}$ & $\begin{array}{l}\text { Larva, } \\
\text { pupa, ergin }\end{array}$ \\
\hline Birnaviridae & dsRNA & $\begin{array}{l}\text { Diptera } \\
\text { (sadece } \\
\text { Drosophila } \\
\text { cinsinde } \\
\text { kaydedilmiş) }\end{array}$ & Ergin \\
\hline Caliciviridae & ssRNA & $\begin{array}{l}\text { Lepidoptera } \\
\text { (sadece } \\
\text { Noctuidae } \\
\text { familyası) }\end{array}$ & Larva \\
\hline Nodaviridae & ssRNA & $\begin{array}{l}\text { Diptera, } \\
\text { Coleoptera, } \\
\text { Lepidoptera }\end{array}$ & $\begin{array}{l}\text { Larva, } \\
\text { ergin }\end{array}$ \\
\hline Picornaviridae & ssRNA & $\begin{array}{l}\text { Diptera, } \\
\text { Lepidoptera, } \\
\text { Orthoptera ve } \\
\text { geniş böcek } \\
\text { familyaları }\end{array}$ & $\begin{array}{l}\text { Larva, } \\
\text { ergin }\end{array}$ \\
\hline Rhabdoviridae & ssRNA & Diptera & Ergin \\
\hline Tetraviridae & ssRNA & Lepidoptera & Larva \\
\hline
\end{tabular}


Autographa califonica nükleopolihedrovirüsü (AcNPV, Baculoviridae), ilk olarak yonca tırtılı böceğinden izole edilmiş, nükleopolihedrovirüs cinsine aittir ve en çok çalışılan örnek bir bakülovirüs tipidir (Demirbağ 1993). Tip türü olması ve bakülovirüslere ait özellikleri yansıtması nedeniyle, bakülovirüslerin biyolojileri hakkındaki bilgiler, AcNPV üzerinden verilmektedir. Nükleopolihedrovirüsler, 1-18 nükleokapsidin bir zarf içerisine gömülmesiyle oluşur. Daha sonra bu zarfa sahip virüsler (virionlar), polihedrin $(28 \mathrm{kDa})$ denilen tek bir proteinden oluşan kristal benzeri cisimler içerisine gömülürler. Bunlar polihedral inklüzyon yapılar (PIB) olarak adlandırıır. PIB içerisine gömülen virüslere gömülü virüsler $(\mathrm{OV})$ adı verilir. Virüse ait protein miktarının \%90'ı polihedrin proteini olmasına rağmen, bu protein virüsün hücrelerde replikasyonu için gerekli değildir. $O$ sadece virüs partiküllerinin tabiat şartlarında korunmasını sağlayan matriks oluşumunda rol alır. Bu nedenle, polihedrin proteinini şifreleyen polh geni, biyoteknolojik uygulamalarda bakülovirüslerin etkili bir şekilde kullanılmalarına imkan sağlamaktadır.

AcNPV'nin replikasyonu enfekte hücrelerin nukleuslarında gerçekleşir (Volkman ve Keddie 1990; Demirbağ 1993; Mikhailov 2003, Slack ve Arif 2007). Şekil 1'de de görüldüğü gibi bu işlem iki aşamada gerçekleşir. Birinci aşamada, nukleus içerisinde nükleokapsidler oluşur. Silindir şeklindeki nükleokapsidler, kapsid denilen tüp benzeri yapı içerisinde DNA'yı içerirler. Tüplerin iki ucunda taban ve kapak denilen yapılar bulunur. Nukleusta oluşan nükleokapsidler sonra nukleus kanallarından geçerek sitoplazmaya ulaşır. Daha sonra hücre zarından tomurcuklanma yöntemi ile zarf kazanarak hücreden ayrılırlar (Şekil 1, H, I, J). Üretilen zarflı virüsler (ekstrasellüler virüsler, BV) hücre kültüründe hücreler arasında in vitro olarak enfeksiyonu taşıma özelliğine sahip, çomak şeklinde virüs formlarıdır (Şekil 1, J). İkinci aşamada ise nukleus içerisinde oluşan nükleokapsidlerin bir kısmı aynı yerde zarf kazandıktan sonra küp şeklindeki protein yapılar içerisine gömülerek polihedral inklüzyon yap (PIB)'ları oluştururlar. AcNPV'ye ait PIB'lerin büyüklükleri 0.5-15 $\mu \mathrm{m}$ arasındadır. Polihedrin proteininden oluşan matriks, PIB'nin genel morfolojisini oluşturur. PIB'ler tabiatta virüs enfeksiyonunun larvadan larvaya taşınmasında rol oynayan yapılardır.

Tabiatta, inklüzyon yapılar, besinler ile birlikte beslenme yoluyla larvalar tarafından alınır. $\mathrm{Bu}$ yapılar, yüksek alkali koşullardan dolayı ortabağırsakta çözülür ve içerisinde bulunan virüs parçacıkları ortabağırsak lümenine salınır (Şekil 1, A). Açığa çıkan virüs parçacıkları özel bir reseptör tarafından tanınır. $\mathrm{Bu}$ tanınma sonucunda virüs parçacıkları membran füzyonu yöntemiyle ortabağırsağın tek tabakalı silindirik epitelyum hücrelerine geçer (Şekil 1, B). Sitoplazmaya ulaşan nükleokapsidler, F-aktin fiberleri vasıtasıyla sitoplazmadan replikasyon bölgesi olan nukleusa geçerler (Şekil 1, C). Virüs DNA'sı burada kapsid örtüden ayrılır. Bu işlem büyük intimalle, DNA moleküllerine tutulu olan arginin bakımından zengin bazik bir proteinin fosforilasyonu neticesinde gerçekleşir. Viral DNA replikasyonu ve transkripsiyon işlemleri nukleusta gerçekleşir (Şekil 1, D).

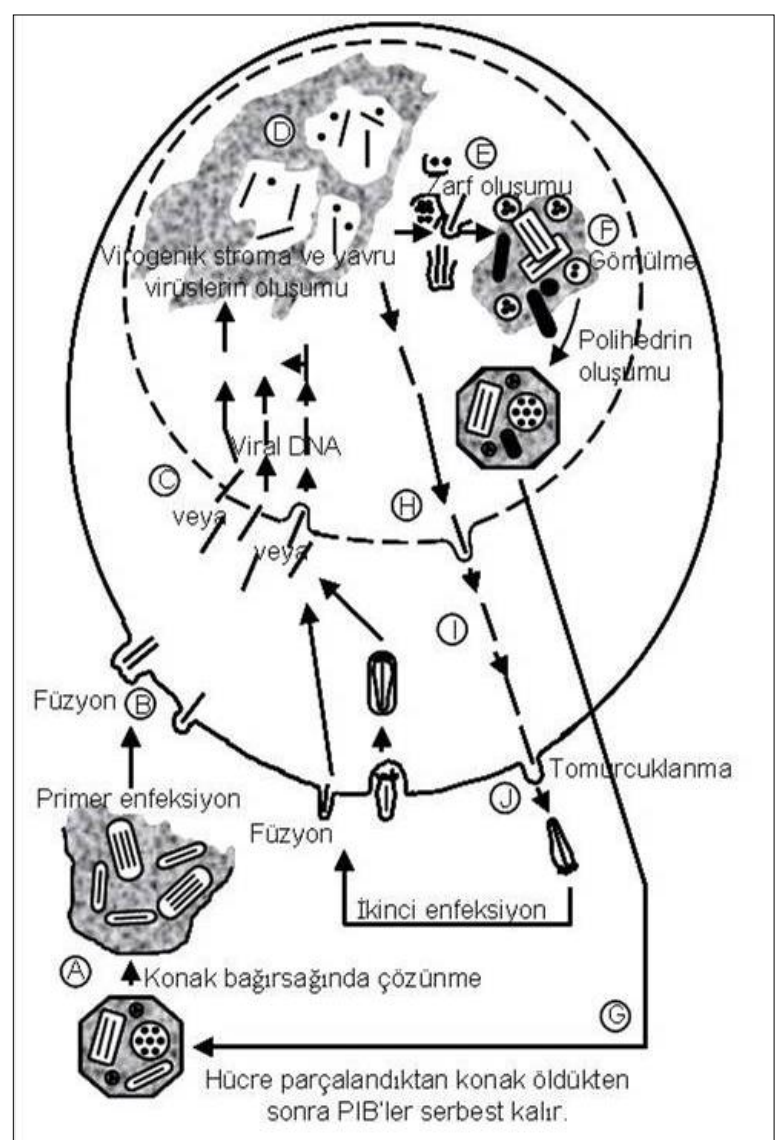

Şekil 1. Bakülovirüslerin replikasyon döngüsü. Konağın ortabağırsağında PIB'ler parçalandıktan sonra virionlar bağırsak hücrelerine saldırır (A, B). Viral kapsid, sitoplazmadan nukleusa geçen viral DNA'dan ayrılır (C). Virojenik stroma içerisinde DNA replikasyonu meydana gelir (D) ve viral alt yapılar sentezlenir. Replikasyonun birinci safhasında nükleokapsidler sitoplazmaya geçer ve hücre zarından zarf kazanıp, tomurcuk virüsleri oluşturarak ayrılır $(\mathrm{H}, \mathrm{I}, \mathrm{J})$. İkinci safhada ise, nukleus içerisinde zarf kazanan virionlar virüs tarafından üretilen polihedrin proteini içerisine gömülerek PIB yapılarını oluştururlar (E, F). Şekil, Strien (1997)'den alınmıştır. 
Replikasyondan (enfeksiyondan 8 saat) sonra nükleokapsid inşaası gerçekleşir. Bu işlem, yavru virüslerin, enfekte olmuş ortabağırsak hücrelerinin bazal kısmından hemolenf içerisine salınması ile sonuçlanır. Daha sonra, ekstrasellüler virüs (ECV) parçacıkları, reseptör bağımlı endositozis yoluyla hemositler, bağ dokusu hücreleri, yağ dokusu, trakeal elementler, kas hücreleri ve Malpighi tüpleri gibi hemolenfe dönük olan hücreleri enfekte ederler. Yen enfekte olan hücrelerde, virüs parçacıkları endozomlar içerisine geçerler. Endozom içerisindeki düşük $\mathrm{pH}$ ECV zarfında mevcut olan glikoproteini (gp64'ü) harekete geçirir. Bu glikoprotein, membran füzyonunu katalizleyerek nükleokapsidlerin sitoplazmaya geçişini sağlar. Bundan sonra salınan nükleokapsidler, hücre kültüründe yeni bir replikasyon işlemini başlatırlar. Replikasyon işleminin ikinci basamağında (enfeksiyondan 12 saat sonra), virüs parçacıkları artık hemolenf içerisine salınmaz. Bunun yerine virüsler, primer ve sekonder olarak enfekte olmuş hücrelerin nukleuslarında yeni yapılan polihedralar içerisine gömülürler (Şekil 1, E, F). Sonuç olarak, larva polihedra ile dolar, virüs tarafından sentezlenen kitinaz ve katepsinaz etkilerine yenik düşen larva ölür (Slack ve ark. 1995), böylece çok sayıda PIB $\left(10^{8}-10^{9}\right.$ /larva $)$ çevreye salınmış olur. İnklüzyon yapılar, mevsimsel beslenme döngülerine sahip böcek populasyonlarında virüs devamlılığında önemli bir rol oynar (Jaques 1985).

Böcek virüslerinin biyolojik mücadele materyali olarak kullanılmaları: Böcekler ve larvaları ziraat ve ormancılıkta büyük kayıplara yol açmaktadır. Böceklerin bu zararlı etkilerini azaltmak veya ortadan kaldırmak için uzun yıllardan beri kimyasal insektisidler kullanılmaktadır. Bu kimyasal insektisitler sadece zararlı böceklere değil, aynı zamanda zararsız ve hatta faydalı böcek ve organizmalara da zarar vermektedir

"İdeal" insektisitler hakkındaki düşünceler 1970'lerden sonra iki sebepten dolayı değişmiştir. Birincisi, çok sayıda zararlı böceğin kimyasal insektisitlere karşı direnç kazandığının gösterilmesidir. $\mathrm{Bu}$ direnç, daha fazla miktarlarda pestisit uygulamalarına veya yeni ve farklı özelliklerde pestisitlerin geliştirilmesine neden olmuştur. İkincisi ise bazı kimyasal insektisitlerin çok uzun süre tabiatta kalmalarıdır. Bu da su ve toprağın kirlenmesine neden olmaktadır. Böylece, kimyasal insektisitler uygulandığı sahada çok uzun süre kalmaları ve yüksek organizasyonlu canlıların besin zincirine girmeleri sebebiyle insan sağlığını tehdit etmektedir. Kimyasal pestisitlerin olumsuz etkileri, biyolojik olarak güvenilir alternatiflerin araştırılmasına sebep olmuştur. Biyolojik mücadele, zararlı böceklere karşı predatör veya parazit, bakteri, virüs, fungus, nematod ve protozoonların veya bunların çeşitli ürünlerinin kullanılmasıyla yapılmaktadır (Fuxa 1998; Katı 2003; Fuxa 2004). Bu böcek patojenleri arasında virüsler, sahip oldukları avantajlardan dolayı biyolojik mücadelede kullanılma yoğunlukları bakımından öne çıkmaktadır (Hunter-Fujita ve ark. 1998).

Virüsler arasında mikrobiyal mücadele etmeni olarak en çok bakülovirüsler tercih edilmektedir (Orlovskaya 1998; Fuxa ve ark. 2002; Toprak ve ark. 2005). Bu kadar çok ilgi görmelerinin nedenleri şu şekilde sıralanabilir: Bakülovirüsler çok spesifiktir. Sadece belirli böcek gruplarını enfekte ederler. Şimdiye kadar, bakülovirüslere karşı herhangi bir dirençe rastlanılmamıştır. $\mathrm{Bu}$ virüslerin moleküler genetikleri detaylı bir şekilde çalışılmıştır (Herniou ve ark. 2001). Ayrıca, bu çalışmalar, bakülovirüslerin genomlarının değiştirilmesine, yabancı genlerin ekspresyonlarına ve insektisidal özelliklerinin geliştirilmesine imkan vermiştir. Tabiatta bakülovirüsler, duyarlı böcek populasyonlarında sayısal olarak azalmalara sebep olur. Bu virüslerin bir biyolojik mücadele materyali olarak kullanılabileceği ilk olarak 1911 'de Reiff tarafından tavsiye edilmiştir. Bugün bakülovirüsler, zararlı böceklerle mücadelede doğal mikrobiyal mücadele etmenleri olarak kabul edilmektedir (Hunter-Fujita ve ark. 1998). Bu amaçla kullanılmakta olan bakülovirüsler Çizelge 2'de gösterilmektedir.

Yukarıda açıklandığı gibi, bakülovirüsler zararlı böceklerin biyolojik mücadelesinde kullanılabilecek mükemmel materyallerdir (Mclntosh ve Grasela, 1994). Bu virüslerin geniş çapta kullanımlarını sınırlayan bazı sebepler vardır. Bunların biri, fonksiyonlarını yavaş olarak yerine getirmeleridir. Diğer önemli bir sebep ise enfeksiyon yapma kapasitelerinin düşük olması ve konukçu spektrumlarının dar olmasıdır. Çeşitli genetik mühendisliği yöntemlerinin uygulanmasıyla, bakülovirüslerin enfeksiyonunun kısa süre içerisinde meydana gelebilmesi, insektisidal etkilerinin geliştirilmesi ve konukçu spektrumunun genişletilmesi mümkün olmuştur. Kısa sürede ölüm, az sayıda virüs üretimine yol açmaktadır. Bu nedenle, kısa sürede öldüren bir virüs, dezavantaj olarak düşünülebilir. Bakülovirüs ekspresyon vektör teknolojisi sayesinde, AcNPV'nin öldürme kapasitesi, böcekler için spesifik toksinler (örneğin Bacillus thuringiensis toksini), hormonlar ve hormonları ayarlayan enzimleri kodlayan gen veya genlerin virüs genomuna dahil edilmesiyle geliştirmektedir (McCutchen ve ark. 1991; O'Reilly ve Miller, 1991). Stewart ve arkadaşları (1991), kuzey Afrika akrebi (Androctonus australis)'nin genomundan böcekler için nörotoksik bir protein kodlayan geni intiva eden bir rekombinant AcNPV oluşturmuştur. Son zamanlarda yapılan çalışmalarla virüsün dokudan dokuya hareketinin, böcek ortabağırsağının primer enfeksiyonu ile başladığı, daha sonra solunum sisteminin virüsün ana güzergahı olduğu tespit edilmiştir. Böylece, enfeksiyon hedefinin değiştirilmesiyle virüsün etkisinin kısa sürede oluşması sağlanabilmektedir. 
Çizelge 2. Biyolojik mücadele amacıyla kullanılan bazı Bakülovirüsler

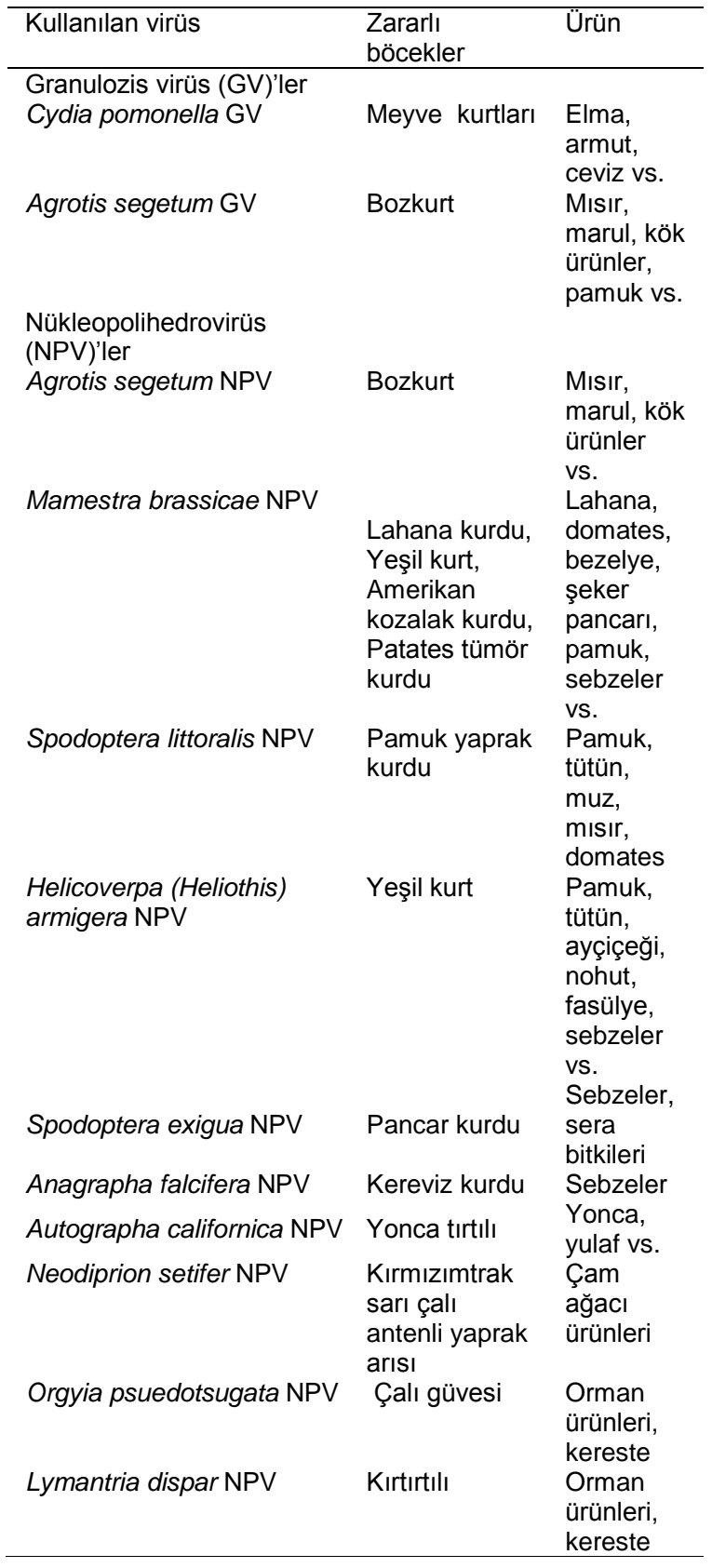

Bakülovirüslerin konukçu spektrumlarının dar olması, bunların kullanımını ekonomik açıdan önemli ölçüde etkilemektedir. Maliyetinin düşürülmesi için aynı virüsün birden fazla zararlı böcek için kullanılması arzu edilmektedir. Virüsün konukçu spektrumunun genişletilmesi, rekombinant tekniklerin kullanılmasıyla mümkün olmaktadır. Bunun için çeşitli zararlı böcekler için seçici toksik olan viral genler bakülovirüslere aktarılarak rekombinant bakülovirüsler inşa edilmektedir (Maeda ve ark. 1993). Bu nedenle, bakülovirüslerin çeşitli konukçular içerisindeki seçiciliğini belirleyen moleküler mekanizmaların tespit edilmesi gerekmektedir. Bakülovirüslere ait ve böcekler için toksik olan çeşitli genler bitkilere aktarılarak bunlarda ekspresyonları sağlanmaktadır. Bu sayede, zararlılara karşı dirençli transjenik bitkilerin elde edilmesi mümkündür. $\mathrm{Bu}$ konuda yapılan çalışmalar neticesinde, Bacillus thuringiensis'e ait böcekler için toksik çeşitli genlerin aktarılmasıyla, transgenik mısır ve tütün bitkileri geliştirilmiştir (Holzman 1995, Jin ve ark. 2003). Günümüzde, bu bitkiler, Amerika ve Avrupa'da başarılı bir şekilde üretilmektedir

Böcek virüslerinin gen ekspresyon vektörü olarak kullanılmaları: Tıbbi, endüstriyel ve zirai bakımdan önemli olan çeşitli viral, bakteriyal, bitkisel ve hayvansal proteinlerin, değişik özelliklerdeki ekspresyon vektörleri aracılığı ile sentezlenmeleri biyoteknolojide büyük önem arzetmektedir. DNA'larından önemli proteinlerin üretilmesinde ekspresyon vektörü olarak yararlanılmalarından dolayı böcek virüsleri son zamanlarda biyoteknolojide yeni bir dönem başlatmıştır. İlaç, toksin ve besin maddesi gibi çeşitli ürünleri kodlayan ilgili yabancı genler, özellikle hücre kültüründe bakülovirüslerin replikasyonu için zorunlu olmayan viral genler yerine klonlanarak, oldukça fazla miktarda üretilmektedirler (Luckow ve Summers 1988, Summers 2006, Yin ve ark. 2007).

Diğer vektörlere göre bakülovirüs ekspresyon vektör sisteminin (BEVS) sahip olduğu üstünlükler ve avantajlar, bunları biyoteknolojinin önemli bir çalışma sahası haline getirmiştir. Pek çok bilim adamı tarafından halen devam ettirilmekte olan, bakülovirüslerin daha etkili bir ekspresyon vektörü haline getirilme ve virüs replikasyonunun moleküler mekanizmalarının anlaşılması çalışmaları, bunların gelecekte biyoteknolojinin daha da önemli bir materyali olmalarına yardımcı olacaktır.

Bakülovirüslerin ekspresyon vektör sistemi olarak kullanılmasının en önemli üstünlüğü, polihedrin ve pl0 proteinlerini kodlayan genlerden (polh ve p10) gelmektedir. Bu proteinler, enfekte olmuş hücrelerde virüs replikasyon siklusunun en geç safhasında fazla miktarda üretilir. Doğada konukçular arasında virüs partiküllerini koruyan inklüzyon yapıların oluşumunda veya virüs partiküllerinin polihedrin içerisine paketlenmesinde polihedrin proteinine intiyaç duyulur. Polihedraya, böceklerin ağız yoluyla enfeksiyonunda intiyaç duyulmasına rağmen, hücre kültüründeki virüs replikasyonunda intiyaç duyulmaz. Bu nedenle, bu genlerin kodlayan bölgeleri çıkarılıp, yerlerine arzu edilen yabancı genler yerleştirilerek bakülovirüs ekspresyon vektör sistemleri geliştirilmekte ve bu vektörler çeşitli yabancı genlerin geniş miktarda ifade edilmesinde kullanılmaktadır. 
Bakülovirüslerin ekspresyon vektör sistemi (BEVS) olarak kullanılmalarına ait ilk çalışmalar, Smith ve arkadaşları (1983) ve Pennock ve arkadaşları (1984) tarafından, Autographa californica nükleopolihedrovirüs kullanılarak Spodoptera frugiperda hücrelerinde $\beta$-interferon'u ve $\beta$ galaktozidaz'ı üretmeleriyle ilgili yapılan araştırmalardır. Sonraki yıllarda BEVS'i kullanılarak tıbbi, ekonomik ve endüstriyel öneme sahip viral, fungal, bakteriyal, bitkisel ve hayvansal orjinli çeşitli rekombinant proteinler bol miktarda üretilmiştir. Günümüzde ise özellikle tıbbi alanda yapılan çalışmalarla çeşitli hastalıklara karşı yeni antijenler, büyüme faktörleri ve kinazlar üretilip, yaygın olarak kullanılmaktadırlar (Vlak ve Keus 1990). Geliştirilen yeni ilaçlarla birlikte yeni tedavi yöntemleri de ortaya çıkarılmıştır. Bunların sonucunda, başta rekombinant ve sentetik olmak üzere birçok yeni aşı bulunmuştur. Yine bu alanda yapılan çalışmalar sayesinde immünoglobulinler, insülin, interferon ve interlökin gibi proteinler de bol miktarda üretilmiştir (Hasemonn ve Capra 1990). Endüstriyel öneme sahip çeşitli bitkisel proteinler de bu sistemde yaygın olarak sentezlenmektedir. Ayrıca, zirai mücadelede zararlı böceklere karşı etkili olan bazı toksik özelliğe sahip proteinler de BEVS'de üretilerek zirai mücadele çalışmalarında kullanılmaktadır (Martens ve ark. 1990).

Virüs genomuna yabancı genlerin yerleştirilme prensipleri: Bakülovirüs genomlarının büyük (80-180 kbp) olmasından dolayı, yabancı DNA'ların bakülovirüs genomuna yerleştirilmesi için bakteri veya maya vektörlerine benzer bir tarzda, restriksiyon enzimleri ve DNA ligaz kullanılarak, direkt olarak çalışmada güçlükler vardır. Polh genini oluşturan virüs genomu bölgeleri, bakteriyal plazmide yerleştirilerek Escherichia coli'de veya polimeraz zincir reaksiyonuyla (PCR) çoğaltılır. Daha sonra, polh geni restriksiyon enzimleri ve ekzonükleazlar kullanılarak elde edilir. Promotorün hemen aşağısında sadece bir restriksiyon enzimi yeri oluşturulması, yabancı DNA'nın yerleştirilmesini kolaylaştırır. Oluşturulan bu son plazmid transfer vektörü veya rekombinasyon vektörü olarak adlandırılır ve çeşitli şekillerde düzenlenir. Böylece, transfer vektörü polh genine ait kodlayan bölgeden mahrum fakat, rekombinasyon için gerekli olan askı bölgelerine sahip ve işaret geni taşıyan bir plazmiddir.

Şekil 2'de, ilgili bir ekzogen proteini ifade etmekte olan rekombinant bakülovirüslerin üretimi, seçimi ve izolasyonu şematik olarak gösterilmektedir. Öncelikle, uygun promotor-okuma zinciri-askı bölgelerini taşıyan bir transfer vektörü, kültür edilmiş böcek hücrelerine ya yabani tip virüs enfeksiyonu sonrası ya da yabani tip virüs DNA'sıyla birlikte transfer edilir. Bu enfeksiyonun ürünlerinden rekombinant virüsler seçilir ve plak saflaştırmasına tabi tutulur. Saf rekombinant virüsler ilgili proteini üretmek için kullanılır.

Tüm rekombinant proteinler için ideal bir gen ifade sistemi henüz geliştirilememiştir. Gen ifadesinde kullanılan bakteriyal, plazmid, faj, viral ve YAC vektörlerinin her biri, rekombinant protein yapısına ve onun kullanılış özelliğine uygunluk gösterir. BEVS diğerlerine göre birçok avantaja sahiptir.

Bunlar, BEVS'inin protein üretimi için ökaryotik bir ortam olması, sistemde çeşitli virüs gen ürünlerinin kullanılabilmesi, sistemin güçlü gen promotorlerine sahip olması, sistemde temporal faktörlerin olması, olgunlaşmamış genlerin (örneğin, cDNA'lar) yüksek oranda ifade edilmesi, büyük genlerin ekspresyonlarının yapılabilmesi, gen ifadesinin $27^{\circ} \mathrm{C}$ 'de meydana gelebilmesi, teknoloji basitliği, sistemin güvenilir olması ve bol miktarda üretimin yapılabilmesidir.

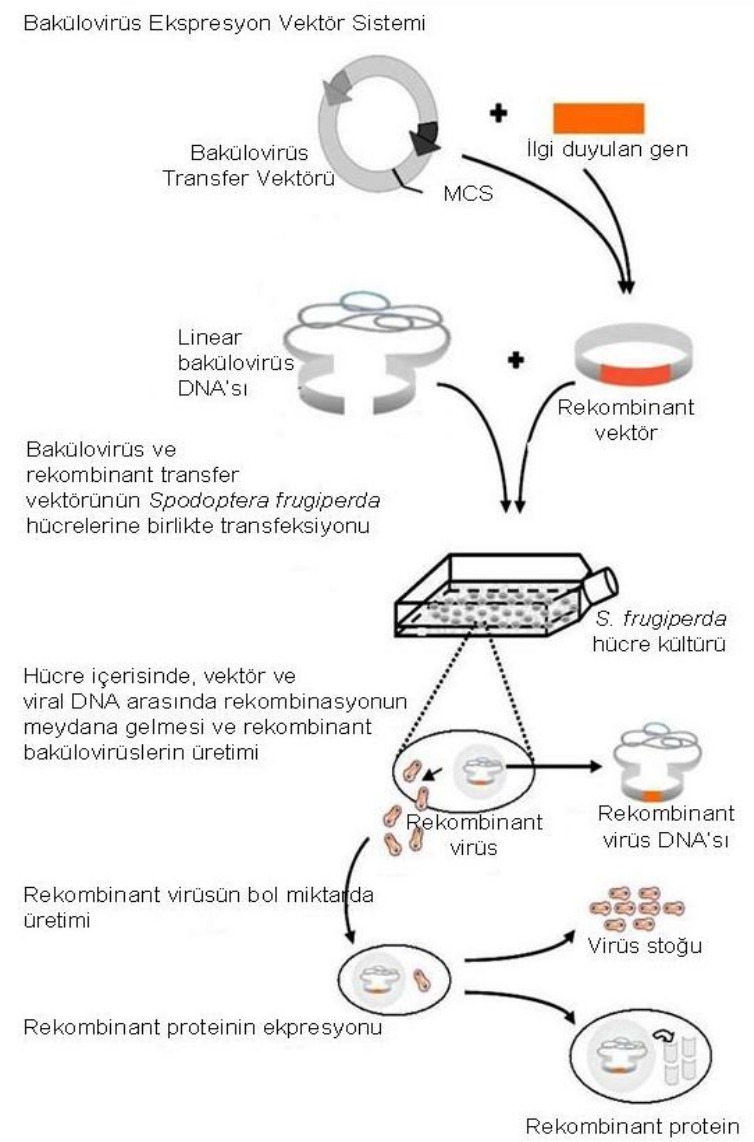

Şekil 2. Bakülovirüs ekspresyon vektör sistemini kullanarak rekombinant gen ifadesi 
Böcek virüslerinin gen terapi vektörü olarak kullanılmaları: Gen terapisi, hastalıkların oluşmasına sebep olan kusurlu genleri düzeltmek için son zamanlarda geliştirilen önemli bir yöntemdir. Araştırıcılar bu amaçla çeşitli yaklaşımlardan faydalanmaktadır. Bunlardan en sık kullanılanı, fonksiyonel olmayan genler çıkarılıp, genomda spesifik olmayan bir yere fonksiyonel genlerin sokulmasıdır. Bir başka yöntemde kusurlu genler homolog rekombinasyonla normal gen ile değiştirilebilirler. Diğer bir yöntemde ise normal gen bu genin işlevinin geri dönmesini sağlayan geri mutasyon ile tamir edilebilir. Ayrıca, belli genlerin regülasyonu uyarılabilir.

Günümüzde, gen terapisi için böcek virüslerinin kullanılmasına yönelik çalışmalar istenen düzeyde olmamasına rağmen, bazı önemli çalışmalar mevcuttur. Bu çalışmalarda gen terapisinde bakülovirüslerin kullanımının diğer gen terapisi yöntemlerine göre avantajları açıkça sergilenmiştir (Hofmann ve ark. 1995; Boyce ve Bucher 1996; Ghosh 2002; Kost ve Condrey 2005; Van Oers 2006). Bunların böcek kaynaklı olmaları, insan bağışıklık sistemine cevap oluşturmamaları ve insanlarda patojen olmamaları gibi özellikleri bu virüslerin gen terapisinde kullanılma nedenlerini artırmaktadır. Ayrıca, vektörlerde rekombinatların seçimine imkan veren işaret genleri, çermeleri, yapay kromozomlar gibi büyük DNA'ların aktarılabilmelerine imkan sağlamaları, çok yüksek verimlilikte rekombinasyon oluşturma kapasitelerine sahip olmaları, serumsuz ortamlarda üretilebilmeleri gibi özellikler bakülovirüsleri önemli gen terapi vektörü haline getirmiştir. Hatta bu özellikler diğer böcek virüslerinde de bulunabilir. Ancak, böcek virüsleriyle yapılan gen terapisi çalışmaları günümüzde bakülovirüslerle sınırlı olup, diğer böcek virüsleri bu anlamda henüz çalışılmamıştır. Bakülovirüslerin bu alandaki çalışılma avantajları, diğer böcek virüslerinin de etkili bir şekilde gen terapisinde kullanılabileceğ yönündeki görüşleri güçlendirmektedir. Bu nedenle, diğer böcek virüslerinin gen terapisi çalışmalarında kullanılması yönünde detaylı çalışmalara intiyaç vardır.

\section{Sonuç}

Yukarıda da belirtildiği gibi, böcek virüsleri son yıllarda zirai mücadele, moleküler biyoloji, gen ekspresyonu ve gen terapisi alanlarında tüm dünyanın ilgisini çeken, bilimsel çalışma materyalleri haline gelmişlerdir. Bu virüslerin, sadece bir alanda değil, çok yönlü olarak insanlığa hizmet etmekte oldukları görülmektedir. İnsanlık belki de bu virüslerden yararlanmanın henüz başlarındadır. Moleküler genetik ve biyoteknoloji alanlarındaki baş döndürücü bir hızla meydana gelen gelişmeler, böcek virüslerini gelecekte çok daha popüler hale getirecek ve çok daha etkin bir şekilde insanoğlunun hizmetine sunacaktır.

\section{Kaynaklar}

Beljelarskaya, S.H. 2002. A baculovirus expression system for insect cells. Mol. Biol. 36: 281-292.

Bilimoria, S.L. 1991. The biolology of nuclear polyhedrosis viruses. s: 1-72. Editör: K.Edouard. Viruses of Invertebrates. Marcel Dekker, 360 sayfa, New York.

Boucias, D.G. ve J. Pendland. 1998. Principles of Insect Pathology. Kluwer Academic Publishers, 537 sayfa, Boston.

Boyce, F. ve N. Bucher. 1996. Baculovirus-mediated gene transfer into mammalian cells. Proc. Natnl. Acad. Sci. 93: 2348-2352.

Charles, J.F., A. Delecluse ve C. Nielsen-LeRoux. 2000. Entomopathogenic Bacteria: From Laboratory to Field Application. Kluwer Academic Publishers, 522 sayfa, Dordrecht.

Demir, İ. 2004. Hyphantria cunea Nükleopolihedrovirüs'ünün Spodoptera frugiperda ve Lymantria dispar Hücre Kültürlerinde Replikasyonunun Karşılaştııılması. Doktora tezi. K.T.Ü. Fen Bilimleri Enstitüsü, Biyoloji Anabilim Dalı, Trabzon.

Demir, İ., R. Nalçacıoğlu, Z. Demirbağ, A.O. Kılıç ve A.O.Beldüz. 2000. Expression of cryIVA and cryIVD genes of Bacillus thuringiensis in baculovirus expression system. Insect Pathogens and Insect Parasitic Nematodes, IOBC WPRS Bull. 23: 267-274.

Demirbağ, Z. 1993. Comperative Replication of Autographa californica Nuclear Polyhedrosis Virus in Abortive and Productive Infections of Insect Cell Lines. Doktora Tezi. Graduat Faculty of Texas Tech University, Texas.

Demirbağ, Z., A.O. Beldüz ve İ. Demir. 1998. Baculovirus'lerin ekspresyon vektörü olarak Biyoteknolojide kullanılması. Tr. J. of Biology. 21: 63-70.

Evans, H. ve M. Shapiro. 1997. Viruses. s: 19-53. Editör: L.A. Lacey. Manual of Techniques in Insect Pathology. Academic Press, 408 sayfa, San Diago.

Flexner, J.L. ve D.L. Belnavis. 2000. Microbial Insecticides. s: 35-62. Editörler: J.E. Rechcigl ve N.A. Rechcigl. Biological and Biotechnological Control of Insect Pest. Lewis Publishers, 392 sayfa, Boca Raton.

Fuxa, J.R. 1998. Enviranmental manipulation for microbial control of insects. s: 255-268. Editör: P. Barbosa. Conservation Biological Control. Academic Press, 396 sayfa, San Diago.

Fuxa, J.R. 2004. Ecology of insect nucleopolyhedroviruses. Agric. Ecosys. Environ. 103: 27-43.

Fuxa, J.R., A.R. Richter, A.O. Ameen ve B.D. Hammock. 2002. Vertical transmission of TnSNPV, TnCPV, AcMNPV and possibly recombinant NPV in Trichoplusia ni. J. Invertr. Pathol. 79: 44-50.

Ghosh, S., M.K. Parvez, K. Banerjee, S.K. Sarin ve S.E. Hasnain. 2002. Baculoviruses as mammalian cell expression vector for gene therapy: An emerging strategy. Molec. Ther. 6: 5-11.

Harrison, R.L. ve B.C. Bonning. 2000. Genetic engineering of biocontrol agents for insects. s: 243-280. Editörler: J.E. Rechcigl ve N.A. Rechcigl. Biological and Biotechnological Control of Insect Pest. Lewis Publishers, Boca Raton.

Hasemonn, C.A. ve J.D. Capra. 1990. High-level production of a functional immunoglobulin heterodimer in a baculovirus expression system. Proc. Natl. Acad. Sci. 87: 3942-3946. 
Hayakawa, T., G.F. Rohrmann ve Y. Hashimoto 2000. Patterns of genome organization and content in lepidopteran baculovirus. Virology. 278: 1-12.

Herniou, E.A., T. Luque, X. Chen, J.M. Vlak, D. Winstanley, J.S. Cory ve D.R. O'Reilly. 2001. Use of whole genome sequence data to infer baculovirus phylogeny. J. Virol. 75: 8117-8126.

Hofmann, C, V. Sandig, G. Jennings, M. Rudolph, P. Schlag ve M. Strauss. 1995. Efficient gene transfer into human hepatocytes by baculovirus vectors. Proc. Natnl. Acad. Sci. 92: 10099-10103

Holzman, D. 1995. Licenses but restricts transgenic corn. ASM News. 61(11): 568-570.

$\mathrm{Hu}$, Y.C. 2006. Baculovirus vectors for gene therapy. Adv. Virus Res. 68: 287-320.

Hunter-Fujita, F.R., P.F. Entwistle, H.F. Evans ve N.E. Crook. 1998. Insect Viruses and Pest Management. John Wiley \& Sons, Chiehester.

Inceoğlu, A.B., S.G. Komita, A.C. Hinton, Q. Huang, T.F. Severson, K. Kang ve B.D. Hammock. 2001 Recombinant baculoviruses for insect control. Pest Man. Sci, 57: 981-987.

Jaques, R.P. 1985 . Stability of entomopathogenic viruses in the environment. s: 285-360. Editörler: K. Maramorosch ve K.E. Sherman. Viral Insecticides for Biological Control. Academic Press, New York.

Jin, H.C, Y.C. Jae, R.J. Byung, Y.R. Jong, J.A. Olszewski, J.S. Sook, D.R. O'Reilly ve H.J. Yeon, 2003. An improved baculovirus insecticide producing occlusion bodies that contain Bacillus thuringiensis insect toxin. J. Invertebr. Pathol. 84: 30-37.

Katı, H. 2003. Doğal ortamlardan izole edilen Bacillus thuringiensis'lerin karakterizasyonu ve insektisida özelliklerinin belirlenmesi. Doktora tezi. K.T.Ü. Fen Bilimleri Enstitüsü, Biyoloji Anabilim Dalı, Trabzon.

King, L.A. ve R.D. Possee. 1992. The Baculovirus Expression System. Chapman and Hall, 230 sayfa London.

Knipe, D.M., P.M. Howley, D.E. Griffin, R.A. Lamb, M.A. Martin, B. Roizman ve S.E. Straus. 2007. Fields Virology (5 Edition). Lippincott Williams \& Wilkins, 3177 sayfa, Philadelphia.

Kost, T.A., J.P. Condreay ve D.L. Jarvis. 2005. Baculovirus as versatile vectors for protein expression in insect and mammalian cells. Nat. Biotechnol. 23(5): 567-575.

Luckow, V.A. ve M.D. Summers. 1988. Trends in the development of baculovirus expression vectors. Bio/Tech. 6: 47-55.

Maeda, S., S.G. Kamita ve A. Kondo. 1993. Host range expansion of Autographa californica nuclear polyhedrosis virus (NPV) following recombination of a 0.6-kilobase-pair DNA fragment originating from Bombyx mori NPV. J. Virol. 67(10): 6234-8.

Martens, J.W.M., G. Honee, D. Zuidema, J.W.M. van Lent, B. Visser ve J.M. Vlak. 1990. Insecticidal activity of a bacterial crystal protein expressed by a recombinant baculovirus in insect cells. Appl. Environ. Microbial. 56: 2764-2770.

McCutchen, B.F., P.V. Choudaryb, R. Crenshaw, D. Maddox, N. Kamita, N. Palekar, S. Volrath, E. Fowler, B.D. Hammock ve S. Maeda. 1991. Development of recombinant baculovirus expressing an insect-selective neurotoxin: Potential for pest control, Bio/Tech. 9: 848852.
McIntosh, A.H. ve J.J. Grasela. 1994. Specifity of baculoviruses. s: 57-69. Editörler: K. Maramorosch ve A.H. Mclntosh. Insect Cell Biotechnology. CRC Press, Boca Raton.

Mikhailov, V.S. 2003. Replication of the baculoviruses genome. Mol. Biol. 37: 250-259.

Miller, L.K. ve L.A. Ball. 1998. The Insect Viruses. Plenum Press, 413 sayfa, New York.

Murphy, F.A, C.M. Fauquet, D.H.L. Bishop, S.A. Ghabrial, A.W. Jarvis, G.P. Martelli, M.A. Mayo ve M. D. Summers. 1995. Virus Taxonomy: The Classification and Nomenclature of Viruses. Sixth Report of the International Committee on Taxonomy of Viruses. Springer-Verlag. Wien.

Nalçacıoğlu, R. 2003. Chile iridescent virüs'ün Bombyx mori hücre kültüründe replikasyonu ve DNA pol ile $m c p$ genlerinin transkripsiyonal analizi. Doktora tezi. K.T.Ü. Fen Bilimleri Enstitüsü, Biyoloji Anabilim Dalı, Trabzon.

O'Reilly, D.R. ve L.K. Miller. 1991. Improvement of a baculovirus pesticide by delection of the egt gene. Bio/Tech. 9: 1086-1089.

Orlovskaya, E.V. 1998. The theoretical basis for using baculoviruses to control forest pests. s: 206-212. Proceeding: Population Dynamics, Impact and Integrated Management of Forest Defoliating Insects. USDA Forest Serive General Technical Report NE-247.

Pennock, G.D., C. Shoemaker ve L.K. Miller. 1984. Strong and regulated expression of Escherichia coli betagalactosidase in insect cells with a baculovirus vector. Mol. Cell. Biol. 4(3): 399-406.

Possee, R.D. 1997. Baculoviruses as expression vectors. Curr. Opin. Biotechnol. 8: 569-572.

Reiff, W. 1911. The Wilt Disease, or Flacherie, of the Gypsy Moth. Contr Ent Lab Bussey Inst Harv, No. 36.

Sezen, K. 2004. Coleoptera takımına ait fındık zararlılarında virüs tespiti ve biyolojik mücadelede kullanım potansiyeli. Doktora tezi. K.T.Ü. Fen Bilimleri Enstitüsü, Biyoloji Anabilim Dalı, Trabzon.

Sezen, K. ve Z. Demirbağ. 2005. Entomopoksvirüsler ve biyolojik kontrol. T. Parazitol. Derg., 29(4): 280-286.

Slack, J. ve B.M. Arif. 2007. The baculoviruses occlusionderived virus: Virion structure and function. Adv. Virus Res., 69: 99-165.

Slack, J.M., J. Kuzio ve P. Faulkner. 1995. Characterization of $\mathrm{V}$-cath, a cathepsin L-like proteinase expression by the baculovirus AcNPV. J. Gen. Virol. 76: 1091-1098.

Smith, G.E., M.D. Summers ve M.J. Fraser. 1983. Production of human beta interferon in insect cells infected with a baculovirus expression vector. Mol. Cell. Biol. 3(12): 2156-2165.

Stewart, L.M.D., M. Hirst, M.L. Ferber, A.T. Merryweather, P.L. Cayley ve R.D. Possee. 1991. Construction of an improved baculovirus insecticide containing an insectspecific toxin gene. Nature, 352: 85-88.

Strien, van, E.A. 1997. Characterization of the Spodoptera exigue baculovirus genome: strucural and functional analysis of a $20 \mathrm{~kb}$ fragment. PhD. Thesis. Wageningen Agricultural University, Wageningen, The Netherlands.

Summers, M. D. 2006. Milestones leading to the genetic engineering of baculoviruses as expression vector system and viral pesticides. Adv. Virus Res. 68: 3-73. 
Tanada, Y. ve H.K. Kaya. 1993. Insect Pathology. Academic Press, San Diego.

Theilmann, D.A., G.W. Blissard, B. Bonning, J.A. Jehle, D.R O'Reilly, G.F. Rohrmann, S. Thiem ve J.M. Vlak. 2005. Baculoviridae, s: 177-185. Eighth report of the international committee on taxonomy of viruses. Academi Press, San Diago.

Toprak, U., Ş. Bayram ve M.O. Gürkan, 2005. Gross pathology of SpliNPVs and alterations in Spodoptera littoralis Biosd. (Lepidoptera: Noctuidae) morphology due to baculoviral. Tarım Bil. Der. 11(1): 65-71.

URL1:http://tr.wikipedia.org./wiki/B\%C3\%B6cek (Ocak 2008).

URL2:http://www.thecanadianencyclopedia.com/index.cfm?P $\mathrm{gNm}=$ TCE\&Params=A1ARTA0004013 (Ocak 2008).

URL3:http://www.dpw.wageningenur.nl/viro/research/baculo\%20biology\%20and\%20biotec hnology.html (Haziran 2007).

Van Oers M. M. 2006. Vaccines for viral and parasitic diseases produced with baculovirus vectors. Adv. Virus Res. 68: 193-253.
Vlak, J.M. ve F.J.A. Keus. 1990. Baculovirus expression vector system for production of viral vaccines. s: 91-128. Viral Vaccines, Advances in Biotechnological Processes. Whiley-Liss, New York.

Volkman, L.E. ve B.A. Keddie. 1990. Nuclear polyhedrosis virus pathogenesis. Seminers in Virol. 1: 249-256.

Yin, J., G. Li, X. Ren, G. Herler. 2007. Select what you need: a comparative evaluation of the advantages and limitations of frequently used expression systems for foreign genes. J. Biotech., 127: 335-347.

\section{İletişim Adresi:}

Yrd.Doc.Dr.İsmail DEMiR

Karadeniz Teknik Üniversitesi

Fen-Edebiyat Fakültesi Biyoloji Bölümü-Trabzon

E-posta: idemir@ktu.edu.tr 